\title{
Prospects of Women Cut Flower Enterprise for Sustainability Approach: A Case Study
}

\author{
Leah" and Amod Sharma
}

Department of Agricultural Economics, Nagaland University, SASRD, Medziphema Campus, District: Dimapur, Nagaland, India

*Corresponding author: hodaec_sasrd@yahoo.co.in

\begin{abstract}
Floriculture in Nagaland has taken a big leap in the state's economy helping the growers, who for the love of flowers can now meet their daily expenditures and other needs through this venture. The demand of fresh cut flowers has brought a huge impact in the Floriculture sector providing income as well as employment especially among the home makers and unemployed youths. The present study being undertaken during the agricultural year 2014-2015 in Dimapur and Kohima districts of Nagaland for the assessment of production and marketing of cut flowers as the study comprises of 75 numbers of sample respondents by following a multi-stage stratified simple random sampling method based on the flower growers. The sample population was categorized under alstroemeria, lilium, anthurium, gerbera and orchid group of growers. The average family size were 5.56, out of which 100.00 per cent were literate, as the worker constitutes 46.66 per cent of total population, the overall total cost of cut flower growers were ₹ 46,600.00/- per acre, as the gross income were ₹ 2,32,520.00/- per acre, the net return were ₹ 1 , $82,782.00 /-$ per acre and overall benefit-cost ratio were 4.97: 1 . There were three (3) marketing channels are identified for the marketing of cut flowers in both the districts, as the Producer's share in consumer's rupees were found highest on channel-I, regarding impact has enhanced by ₹ 1,20,131.80/- per acre to their annual income, while ₹ 23,101.52/- was increase in their annual expenditure on food items as well as on their annual savings, also an attempt has been made to study the constraints faced by the cut flower growers during the production viz; requirement of more care was foremost followed by lack of timely availability of planting materials, while the marketing constraints include the lack of knowledge on post harvest techniques as the foremost followed by lack of storage facilities and it was least on lack of transportation facilities etc;
\end{abstract}

Keywords: Impact, income, flower, growers, production, marketing

The most colorful and beautiful sector of Horticulture is known as Floriculture, which is the growing of cut-flowers, potted flowering and foliage plants and bedding plants in greenhouses and / or in open fields. As it was well said that "Man is born with flowers, lives with flowers and finally dies with flowers", which itself signified the celebrations and everyday lives. Flowers being considered as an adorable creation of God, befits all occasions, be it at birth, wedding, graduations, funerals, Mother's Day, St. Valentine's Day, Easter and Christmas which area the peak periods of demand for flowers and plants with its meaning in expressing their feelings by presenting flowers to their loved ones. Landscaping has also made its way in the industry which has an immense scope for entrepreneurs who love to work out. Flowers are luxurious products with high social value and rarely used for food (Getu, 2009). The world market for cut flowers has been growing as the world trade floriculture is estimated at more than $\$ 120$ billion, which is growing at the rate of around 15.00 per cent annum despite recent global financial crisis, more than 140 countries are involved in flower cultivation in the world. Developed countries account for more than 90.00 per cent of the total world trade in floriculture products (Kumar, 2011). Due to globalization and its effect on income, the world production is growing at a rate of 10.30 per cent per year and its growth rate is expected to reach US\$ 25 Billion on 2012 (Exim, 2010). 
Even the Government of India acknowledges the potential of the floriculture industry and has conferred 100.00 per cent export oriented industry status (APEDA, 2017). Cut flowers are defined as blossoms from flowering plants sold as stems, bunches, or arrangements. Cut Flowers are parts of plants, characteristically including the blooms or "inflorescences" and some attached plant materials, but not including roots and soil (USITC, 2003). The flowers can be fresh, dried, or preserved. Cut flowers are usually sold in bunches or as bouquets with cut foliage. The production of cut flowers is specifically known as the cut flower industry. India is bestowed with several agro-climatic zones conducive for production of sensitive and delicate floriculture products throughout the year as floriculture in India is characterized by growing traditional and cut flowers under open field conditions and protected environment condition respectively. The important cut flowers grown in India are rose, gladioli, gerbera, carnation, etc. More than 77.00 per cent of the floriculture units are based in Karnataka, Andhra Pradesh and Tamil Nadu. With the technical collaborations from foreign companies, the Indian floriculture industry is poised to increase its share in world trade. With urbanization and increase in disposable income level, the demand for floriculture products has increased significantly as a result of which there has been an increasing demand for cut flowers like rose, gladiolus, carnation, gerbera, orchid, carnation, gerbera, lilium etc.

India's total export of floriculture was 22,485.21 MT worth ₹ 455.90 crores in 2013-14. (APEDA, 2015). There are more than 300 export-oriented units in India. The export basket of flowers in India is viz; dry flowers (71.00 per cent), cut flower (18.00 per cent), live plants (9.00 per cent), loose flowers (1.00 per cent) and fresh bulbs (1.00 per cent). The severe winter in the European countries is also a factor to India which enjoys moderate climate all throughout the year. These favourable factors offer Indian Foreign Exchange earning potential of ₹ 1,000 million annually. The foreign exchange export earning was through destinies viz. USA, Germany, UK, Italy, Saudi Arabia, Netherlands, Spain, Sri Lanka, Japan and United Arab Emirates.

The North-eastern region with its rich and dense forests, exotic and cultivated floral treasure is a storehouse of exotic flora of which many are indigenous to this part of the country. Because of the congenial climate, unexplored potential, availability of sufficient land and other inherent strengths, the North Eastern region of the country provide a suitable alternative. The region being totally free from any external forces holds great promise for commercial floriculture. The climate of this region has given rise to huge wealth of ornamental plants like anthurium, rose, carnation, gerbera, chrysanthemum and orchids like dendrobium, cymbidium etc (APEDA, 2015). The Indian government is presently supporting large-scale commercial cultivation of about 200 varieties of exotic orchids through tissue culture in this region. The scheme aimed at the holistic development of all the horticulture crops in all the districts of the north eastern and himalayan states. With its new name, Horticulture Mission for north east and himalayan states has emerged as the most significant contributing factor to bring about a revolutionary change in the entire horticultural scenario of the regions and it has become a people's programme now.

Table 1: Area and Production of Flowers in India (2009-2016)

\begin{tabular}{|c|c|c|c|c|}
\hline \multirow[b]{2}{*}{$\begin{array}{l}\text { Sl. } \\
\text { No. }\end{array}$} & \multirow[b]{2}{*}{ Year } & \multirow[b]{2}{*}{$\begin{array}{c}\text { Area } \\
\text { (in ‘000 ha) }\end{array}$} & \multicolumn{2}{|c|}{ Production } \\
\hline & & & $\begin{array}{l}\text { Loose flower } \\
\text { (in ‘ } 000 \mathrm{mt} \text { ) }\end{array}$ & $\begin{array}{l}\text { Cut flower } \\
\text { (in lakh no's) }\end{array}$ \\
\hline 1. & $2009-10$ & 183 & 1,021 & 66,671 \\
\hline 2. & 2010-11 & 191 & 1,031 & 69,027 \\
\hline 3. & 2011-12 & 254 & 1,652 & 75,066 \\
\hline 4. & 2012-13 & 233 & 1,729 & 76,732 \\
\hline 5. & 2013-14 & 242 & 1,847 & 79,432 \\
\hline 6. & 2014-15 & 247 & 1,971 & 80,002 \\
\hline 7. & 2015-16 & 254 & 2,047 & 81,156 \\
\hline
\end{tabular}

Source: National Horticulture Board, 2017.

The most remarkable impact has been brought about by technology interventions coupled with a complete package of inputs. Inputs like quality planting material, greenhouse, drip irrigation system, feeds and fertilizers have a direct and positive impact on the overall development of floriculture (Anon. Floriculture Today). An impressive achievement in floriculture sector is seen in Northeastern states of Arunachal Pradesh, Nagaland, Manipur, Mizoram and Sikkim. Arunachal Pradesh is leading both in 
area $(1,220$ hectares) and production (286 million stems) followed by Mizoram, Sikkim and Nagaland (Anon, 2017).

Floriculture has emerged as a major diversification option in the agri-business in recent years. Floriculture has the potential to contribute substantially to the growth of the agriculture sector in the state. The State department of Horticulture has identified a few flowers for commercial production with an eye on the export market. Lillium, anthurium, alstroemeria, carnation, roses etc; are the identified flowers. The Department has brought modern technology intervention of Flower cultivation along with imported planting materials and inputs from international countries like Netherlands and Israel. Besides the cultivation of flowers, the Nagaland government has initiated in promoting commercial flower production as well as for ornamental purpose by organizing Flower exhibitions as well flower arrangement competitions where flower growers and florists come together to exhibit the diverse flora of Nagaland.

Table 2: Flower production in North Eastern Region during 2012-13

\begin{tabular}{ccccc}
\hline $\begin{array}{c}\text { S1. } \\
\text { No. }\end{array}$ & States & $\begin{array}{c}\text { Area } \\
\text { (in ‘000 ha) }\end{array}$ & $\begin{array}{c}\text { Loose flower } \\
\text { (in `000 MT) }\end{array}$ & $\begin{array}{c}\text { Cut flower } \\
\text { (in lakhs) }\end{array}$ \\
\hline 1 & $\begin{array}{c}\text { Arunachal } \\
\text { Pradesh }\end{array}$ & 0.2 & 0.01 & 297.00 \\
2 & Assam & 1.80 & 11.70 & $3,750.00$ \\
3 & Mizoram & 0.16 & 166.83 & 605.22 \\
4 & Nagaland & 0.01 & - & 96.66 \\
5 & Sikkim & 0.22 & 26.50 & 214.10 \\
\hline
\end{tabular}

Source: www. Indiastat.com, 2014.

In order to bring about oneness among the growers and to promote awareness about the importance of commercial flower cultivation, Nagaland Flower Growers' society was established by the flowers growers which is helping both large and small growers to come together to promote and sell their flowers. Commercial production of rose and lillium has since started and the same are being exported to both domestic and foreign markets. The quality of flowers in Nagaland is of international scenario and Naga Fresh Flowers are prestigious among the floriculture today. (Anon. The Telegraph, 2018). About 10 hectares area has been developed under hi-tech and low cost greenhouses, flowers which are being grown extensively in the State are anthurium, lilium, rose, orchids, heliconia, Bird of paradise etc; zantedeschia and alstroemeria are the new exotic flowers adopted for cultivation even the dried flowers are also produced and sold outside the State which is of great demand. The area under floriculture in Nagaland is about 450 hectares with annual production of 15.36 lakh numbers of cut flowers.

Table 3: Crop-wise Area, Production and Productivity of Flowers in Nagaland during 2013-2014

\begin{tabular}{ccccc}
\hline $\begin{array}{c}\text { S1. } \\
\text { No. }\end{array}$ & Crops & $\begin{array}{c}\text { Area (in } \\
\mathbf{M}^{\mathbf{2}} \text { ) }\end{array}$ & $\begin{array}{c}\text { Production } \\
\text { (in stems) }\end{array}$ & $\begin{array}{c}\text { Productivity } \\
\text { (stems/(M) }\end{array}$ \\
\hline 1. & Lilium & 26,600 & $18,26,000$ & 70 \\
2. & Rose & 17,400 & $11,31,000$ & 65 \\
3. & Alstroemeria & 30,600 & $21,42,000$ & 70 \\
4. & Orchid & 6,000 & $1,20,000$ & 20 \\
5. & Gerbera & 9,400 & $8,46,000$ & 90 \\
\hline
\end{tabular}

Source: Department of Horticulture, Government of Nagaland, 2015.

Apart from offering greenhouses and quality planting materials to the entrepreneurs, the State Department of Horticulture also provides buy-back arrangements, technical support, cold room facilities, etc. Thus, the introduction of Horticulture Mission has been a big blessing for the State of Nagaland and most importantly for the flower growers of the State. So far growth target of 8.00 per cent of GDP is a concern the agriculture has to grow by 4.00 per cent only, whereas the horticulture has to grow more than 7.00 per cent with contribution of 18.80 per cent in total agriculture production and 52.00 per cent in total agricultural export. Floriculture industry has witnessed remarkable growth during the last five years. With urbanization and increase in disposable income level, the demand for floriculture products has increased significantly. As a result, there has been an increasing demand for cut flowers like rose, gladiolus, carnation, gerbera, orchid, carnation, gerbera, lilium, etc; which are grown abundantly in the state.

It is estimated about 70,000 stems of cut flowers are being produced in a week in the State. As farmer needs subsidiary occupation, which may lead to generate additional employment and income then Horticulture sector is the best. Therefore, Government as well as local inhabitants should 
get more attention for the implementation of those crops, which may generate more income as well as employment with minimum investment of input has been proposed. As Dimapur is a potential hub for flower growers in Nagaland as the climate favours the growth of its, moreover, the flower producers in these areas has been scope. In view of the context mentioned that its required proper evaluation of "Production and Economics of cut Flowers Growers in Nagaland", with the following specific objectives:

1. To estimate the income and employment generated from cut flower enterprise,

2. To study the constraints faced by the flower growers and suggestion to improve the production and marketing of cut flowers.

\section{DATABASE AND METHODOLOGY}

A multi stage stratified random sampling technique was adopted for the selection of the cut-flower entrepreneurs, a total sample of 75 cut flower growers were selected, while in the first stage by following the random sampling method from Kohima and Dimapur districts were seleted, while in the second stage 15 numbers of each anthurium, gerbera, orchid growers from Dimapur district and 15 each growers of alstroemeria and lilium from Kohima district were selected, then a list is obtained from the State Horticulture Department for the distribution of total respondents according to size of holding in the district under cut-flower cultivators. Therefore, for the present study a total of 45 numbers of cut-flower growers from Kohima and Jakhama blocks were selected, while from the Dimapur district a total of 30 numbers of cut-flower growers were selected from Medziphema and Chumukedima blocks areas, respectively.
Table 4: Number of selected respondents on the basis of cut flowers grown

\begin{tabular}{|c|c|c|c|}
\hline $\begin{array}{l}\text { Sl. } \\
\text { No. }\end{array}$ & $\begin{array}{c}\text { Name of the } \\
\text { flower }\end{array}$ & $\begin{array}{c}\text { Total numbers of cut } \\
\text { flower growers }\end{array}$ & $\begin{array}{c}\text { Sample size } \\
\text { (n) }\end{array}$ \\
\hline 1 & Alstroemeria & $50(25.00)$ & $15(20.00)$ \\
\hline 2 & Lilium & $50(25.00)$ & $15(20.00)$ \\
\hline 3 & Anthurium & $25(12.50)$ & $15(20.00)$ \\
\hline 4. & Gerbera & $25(12.50)$ & $15(20.00)$ \\
\hline \multirow[t]{2}{*}{5} & Orchid & $50(25.00)$ & $15(20.00)$ \\
\hline & Total & $200(100.00)$ & $75(100.00)$ \\
\hline
\end{tabular}

The figures in the parenthesis indicates percentage to the total.

\section{RESULTS AND DISCUSSION}

\section{Income and Employment impact from cut flower production}

Table 5 reveals that cut flower cultivation has made a positive impact on the annual income, annual expenditure on food as well as on their annual savings too. Based on the present study it was found that on overall farm there was an increase of ₹ 1,20,131.80/- in their annual income, ₹ 23,101.52/increase in their annual expenditure on food, an increase of ₹ 1,12,160.60/- and ₹ 1,28,102.90/- were observed in case of annual income in Dimapur and Kohima district respectively. The overall expenditure and profit of cut flower growers were ₹ 96,800/- and ₹ 1,17,000/- respectively.

Table 6 reveals that an average of 76.51 man days was generated under Kohima district and 84.79 man days in Dimapur district. Thus an average of 80.65 man days was generated under cut flower in both the selected districts. The cut flower enterprise has made a positive impact on the annual income, annual expenditure on food. Based on the present study it was found that there was an average

Table 5: Impact on cut-flower growers annual income in Nagaland (in ₹)

\begin{tabular}{|c|c|c|c|c|c|c|}
\hline \multirow[t]{2}{*}{ S1. No. } & \multirow[t]{2}{*}{ Cut-flower } & \multicolumn{2}{|c|}{ Before } & \multicolumn{2}{|c|}{ After } & \multirow[t]{2}{*}{ Remarks } \\
\hline & & Mean & SD & Mean & SD & \\
\hline 1 & Alstroemeria & 37043.33 & 2700.06 & 90106.67 & 12581.7 & Increased by ₹ 53,063.34/- \\
\hline 2 & Lilium & 80650.00 & 802.20 & 200163.30 & 1536.51 & Increased by ₹ 1,19,513.30/- \\
\hline 3 & Anthurium & 140670.00 & 1737.79 & 256040.00 & 2195.99 & Increased by ₹ $1,15,370.00 /-$ \\
\hline 4 & Gerbera & 156920.00 & 1471.32 & 300624.00 & 2878.29 & Increased by ₹ $1,43,704.00 /-$ \\
\hline 5 & Orchid & 105908.30 & 826.54 & 274916.70 & 2793.75 & Increased by ₹ $1,69,008.30 /-$ \\
\hline & Overall & 104238.30 & 1507.58 & 224370.10 & 4397.25 & Increased by ₹ $1,20,131.80 /-$ \\
\hline
\end{tabular}


Table 6: Impact on cut-flower grower employment generated annually in Nagaland

\begin{tabular}{ccccccc}
\hline S1. No. & Cut-flower & \multicolumn{2}{c}{ Before } & \multicolumn{2}{c}{ After } & \multirow{2}{*}{ Remarks } \\
\cline { 3 - 6 } & & Mean & SD & Mean & SD & \\
\hline 1 & Alstroemeria & 74.38 & 15.21 & 88.44 & 16.47 & Increased by 14.06 mandays \\
2 & Lilium & 78.45 & 14.34 & 89.64 & 16.73 & Increased by 11.19 mandays \\
3 & Anthurium & 77.00 & 14.23 & 96.14 & 18.34 & Increased by 19.14 mandays \\
4 & Gerbera & 61.00 & 12.34 & 79.84 & 14.45 & Increased by 18.84 mandays \\
5 & Orchid & 42.00 & 10.34 & 50.70 & 11.23 & Increased by 8.70 mandays \\
& Overall & $\mathbf{6 8 . 0 0}$ & $\mathbf{1 3 . 4 5}$ & $\mathbf{8 0 . 9 5}$ & $\mathbf{1 4 . 4 8}$ & Increased by 14.38 mandays \\
\hline
\end{tabular}

increase of ₹ 1,20,131.80/- in their annual income, ₹ 23,101.52/- increase in their annual expenditure on food and also increase in their annual savings too, which clearly indicate that there in an impact on socio-economy of cut flower growers in both the districts.

Table 7, the major contrains prevailed in the study area are requirement of more care in cut flowers due to their low shelf life, lack of timely availability of planting materials and lack of government support in terms of monetary as well as technical support. The other problems identified were high initial investment of labour and money, pest and disease attack, need of more technical skill, water scarcity during critical period and lack of equipment and other items.

Table 7: Constraints faced by the growers during the production of flower $(\mathrm{N}=75)$

\begin{tabular}{cccc}
\hline $\begin{array}{c}\text { Sl. } \\
\text { No. }\end{array}$ & Constraints & Frequency* & Percentage \\
\hline 1 & $\begin{array}{c}\text { Water scarcity during } \\
\text { critical period }\end{array}$ & 38 & 50.67 \\
2 & $\begin{array}{c}\text { Lack of equipment and } \\
\text { other items }\end{array}$ & 31 & 41.33 \\
3 & Need more technical skill & 45 & 60.00 \\
4 & Pest and disease attack & 49 & 65.33 \\
5 & High initial investment & 51 & 68.00 \\
6 & Require more care & 58 & 77.33 \\
7 & Lack of government & 56 & 74.67 \\
8 & support & 54 & 72.00 \\
& Lack of timely availability & 54 & \\
\hline
\end{tabular}

${ }^{*}$ Multiple responses of respondents.

Table 8 shows the main marketing constraints / problems identified in the study area. The major problems prevailed in the study areas were Lack of knowledge in post harvest techniques (preserving of cut flowers), lack of storage facilities, lack of government support and difficulty in packing materials. The other problems identified were price fluctuation, insufficient market knowledge, lack of trainings in the floriculture enterprise, lack of credit facilities for enterprise, absence of grading system, need of more managerial skill and lack of transportation facilities.

The per acre cost of cut flower cultivation for the sample grower were ₹ 46,260.60/-, ₹ 51,089.51/-, ₹ $42,880.32 /$, ₹ $45,310.21 /$ - and $₹ 47,463.48 /-$, respectively for alstroemeria, lilium, anthurium, gerbera and orchid, with an average of ₹ 46,600/-. The benefit cost ratio over total cost for the sample group of growers in the study area was 4.97: 1, the benefit cost ratio over variable cost per acre from cut flower cultivation was found to be 4.87: 1, 6.28: 1, 6.49: 1, 2.95: 1 and 8.29: 1 for alstroemeria, lilium, anthurium, gerbera and orchid category of growers respectively.

Table 8: Constraints faced by the growers during the Marketing of flowers ( $\mathrm{N}=75)$

\begin{tabular}{|c|c|c|c|}
\hline $\begin{array}{l}\text { Sl. } \\
\text { No. }\end{array}$ & Constraints & Frequency* & Percentage \\
\hline 1 & Absence of grading system & 45 & 60.00 \\
\hline 2 & Lack of storage facilities & 70 & 93.33 \\
\hline 3 & $\begin{array}{c}\text { Difficulty in packing } \\
\text { materials }\end{array}$ & 65 & 86.67 \\
\hline 4 & $\begin{array}{l}\text { Lack of trainings in the } \\
\text { floriculture enterprise }\end{array}$ & 55 & 73.33 \\
\hline 5 & $\begin{array}{c}\text { Lack of credit facilities for } \\
\text { enterprise }\end{array}$ & 51 & 68.00 \\
\hline 6 & Lack of institutional finance & 67 & 89.33 \\
\hline 7 & $\begin{array}{c}\text { Lack of post harvest } \\
\text { techniques (preserving of } \\
\text { cut flowers) }\end{array}$ & 72 & 96.00 \\
\hline
\end{tabular}




\begin{tabular}{cccc}
8 & Lack of government & 67 & 89.33 \\
9 & support & & \\
9 & Price fluctuation & 58 & 77.33 \\
10 & Insufficient market & 57 & 76.00 \\
& $\quad$ knowledge \\
11 & Need more managerial skill & 35 & 46.67 \\
12 & Lack of transportation & 28 & 37.33 \\
$\quad$ facilities & & \\
\hline
\end{tabular}

${ }^{*}$ Multiple responses

\section{CONCLUSION}

Further study reveals that, there is not much awareness about preservation and storage of cut flowers by the flower growers which allow the intermediaries to buy the produce at a lower price and sell it at much higher rate at the consumer level. The exporting of Cut flowers to other states of the country or other countries so formation of firm co-operative marketing society should be encouraged at the block and District level for selling their produce at fair price efficiently in time. Government should make a suitable and applicable policy to solve the marketing problems faced by the Cut flower growers. Lack of Financial support by the Government agencies and also necessary steps should be taken up by the government implementing news schemes with expert help and suggestions. Yearly inspection of units by the Government officials whenever required by the growers should be encouraged. A little effort from both the government and public-privatepaternership may be encouraged for better results in the cut flower industry of Nagaland. Research and development should be directed towards the development of disease and pest resistant through high yielding varieties or resistance varieties of cut flower in the study area. Growers should be trained to adopt integrated pest and nutrient management and the promoting farm mechanization in cut flower cultivation.

\section{REFERENCES}

Anonymous. 2013. Annual Report of FAO STAT. Published by Food and Agriculture Organization, Rome.

Anonymous. 2015. Agricultural Produce Processing and Export Development Authority (APEDA). Export Status in India. Ministry of Commerce and Industry, New Delhi.

Anonymous. 2017. Indian Horticulture Database. National Horticulture Board, Ministry of Agriculture, Government of India, Gurgaon, Haryana.

Anonymous. 2017. Statistical Hand of Nagaland (Various issues). Published by Directorate of Economics \& Statistics, Kohima, Nagaland.

Govindasamy, P.C. and Agoramoorthy and Hsu. M.J. 2012. Impact of floriculture development enhances livelihood of India's rural women. Journal of Agriculture and Rural Development in the Tropics and Subtropics, 11(1): 69-76.

Kaviarasan, K., Singh, D.R., Arya, P. and Kumar, A. 2015. Economics of production and marketing of chrysanthemum flowers in Krishnagiri District of Tamil Nadu.

Manju, D., Punia, S. and Hasija, R.C. 2010. Constraints in flower cultivation: a sociological appraisal. Environment and Ecology, 28(1-B): 512-15.

Rahim, I.B., Kazi, M.B. and Sarkar, Debashis. 1998. Economics of Export Oriented Horticultural Crops in Sikkim. AgroEconomic Research Centre, Visva-Bharati, West Bengal.

Rao, A.N. 1997. Higher Employment and Income Potential of Horticultural Crops. Indian Journal of Agricultural Economics, 52(3): 12-15.

Rathakrishnan, T. and Padma, S.R. 2014. Commercial Floriculture: A High Value Enterprise. The Andhra Agricultural Journal, 61(3): 704-708.

Shreedevi, B.C. and Sonnad, J.S. 2014. Production and marketing constrains of orchids in Karnataka. Karnataka Journal of Agricultural Sciences, 27(3): 363-364.

Singh, S.B. and Punitha, P. 2012. Entrepreneurship development through anthurium flower - a case study of Mizoram, North-east India. Indian Research Journal of Extension Education, 12(3): 74-78.

Sinha, Nishi. 1995. Towards the target of full employment. Yojana, 39(14): 21-24. 